\title{
18
}

\section{Reforms and challenges of the social security system}

\section{Qun Shi}

The Chinese social security system is undergoing a series of reforms. These reforms are often the government's short-term responses to imminent financial and social pressure. The long-term impacts, especially those on economic efficiency, are often ignored.

The background of the Chinese social security system reform is unique. Like many other countries (mainly more advanced economies), China is facing an unprecedented demographic transition-an aging population. However, population aging in China is taking place at a much lower level of GDP per capita (Peterson 1999). In the meantime, China is undergoing transition to a market-oriented economy. This is a challenge for the old Chinese social security system and is likely to remain a challenge for many decades.

The old Chinese social security system originated from the command economy era, when the Communist government's development strategy was based on rapid industrialisation. This strategy taxed the agricultural sector, which included 80 per cent of the Chinese population, to cross-subsidise the industrial sector (Wen 2000). The social security system formed at the time was a dual system: a rural system, based on the People's Communes, ${ }^{1}$ that was very elementary, and an urban system that was much more generous and was based on the work unit system. ${ }^{2}$

In rural areas, farmers were organised into People's Communes, and the commune was responsible for providing minimum subsistence to each member. Heavy agricultural taxation, and the need to provide this minimum living, led to a relatively 
equal distribution of available food among members, leaving individual farmers with little incentive to work hard to improve their welfare (Wen 2000). Social security assistance from the government was very limited and only available when the commune could not provide subsistence to its members, such as when there was a natural disaster.

People in cities had much more generous social security provisions and other related welfare benefits. The vast majority of them were guaranteed a job by the government in work units of the public sector and became lifetime employees of the work units. Such jobs also carried generous social security and welfare benefits for the employees and their family members, as specified by the Labour Insurance Regulations (LIR). ${ }^{3}$ By the late 1970 s, the urban social security system was based around the work unit, with individual work units financing the benefits of its members and their families. This was feasible since the government would support them with budgetary appropriations if necessary. Urban residents (and their family members) who were not assigned jobs could receive limited assistance from the Ministry of Civil Affairs (MCA).

This dual system relied heavily on other policies that segregated the rural and urban areas at the time. These policies included the household registration system (HRS), ${ }^{4}$ restrictions on travel, and comprehensive rationing of consumption goods. The HRS was the most important policy and remains in force. These policies effectively curbed domestic migration in general, and rural-to-urban migration in particular (Zhao 2003).

The initiation of transition led to the collapse of the People's Commune system in the early 1980s, a process which essentially destroyed the rural social security system. At present, government-guaranteed access to land is often regarded as the social security provided by the government (Zhao and Wen 1999; Wen 2000). Most reforms to China's social security system have occurred in the urban areas.

Facing demographic and economic transitions, the Chinese government's major social security reform challenge is to transform the old system into a new one that is in line with a market-oriented economy. The new system will have implications for economic efficiency. This chapter will analyse this issue, using selected social welfare programs as case studies. ${ }^{5}$

Economic transition changed the environment of the old urban social security system. First, the previous development policy of cross-subsidising the industrial sector by the agricultural sector was abolished. This meant that the state's control 
and its capacity for mobilising resources from the agricultural to the industrial sector were reduced. As a result, it became increasingly difficult for the central government to subsidise state-owned enterprises (SOEs). ${ }^{6}$

Second, labour market and SOE reforms had gradually undermined the foundation of this work unit-based social security system. Reforms included using labour contracts to replace the previous lifetime employment guarantee by the government (Meng 2000) and policies to transform SOEs into independent economic agents in a market economy. ${ }^{7}$

The 'SOE-based ${ }^{8}$ security system' (LIR) had three major problems

- As an insurance system, it lacked diversifications of risk. The individual SOEbased insurance could not share risks among a large population. This reduced the effectiveness of the system. For example, SOEs with a high retireeemployee ratio had a higher pension burden.

- As a social security program, the scheme had shrinking coverage, when the emerging private sector was left out of the mandatory coverage of the scheme (see Table 18.1).

- The system prevented efficient specification of functions because each SOE had to be a production-based firm, an insurance company and a superannuation fund.

Table 18.1 Employment structure by ownership in urban China, 1980-99 (percentages)

\begin{tabular}{lcccc}
\hline & & & Other & \\
Year & State-owned & Collective-owned & ownership & Total \\
1980 & 76 & 23 & - & 99 \\
1985 & 70 & 26 & - & 96 \\
1990 & 62 & 21 & 1 & 85 \\
1995 & 57 & 16 & 5 & 78 \\
1996 & 55 & 15 & 5 & 75 \\
1997 & 53 & 14 & 5 & 73 \\
1998 & 43 & 9 & 8 & 60 \\
1999 & 40 & 8 & 8 & 56 \\
\hline
\end{tabular}

Note: Figures are based on total urban employment, including all people who worked and received income during the year.

Source: Figures are from State Statistical Bureau, 2001. China Statistical Yearbook, China Statistical Press, Beijing:8, 14 . 
The first two problems diminished the provision of an adequate social safety net to people in need in cities, such as employees in loss-making SOEs and employees in the private sector. The third prevented SOEs from becoming independent firms in a market economy.

Reforms of the urban social security system started in the mid 1980s. However, the major progress was in the 1990s, after the deepening of the SOE reform and the pressure from the large numbers of redundant workers it generated. Although the official number of retrenchments appears to be moderate (Table 18.2), it is estimated that SOEs had about 20-30 million excess employees by the late 1990s (Zhang 1999:69).

\section{THE UNEMPLOYMENT INSURANCE PROGRAM}

Along with the labour contract system, the government established an unemployment insurance program in $1986 .{ }^{9}$ However, this program was only to provide insurance for some redundant SOE employees, especially those who had lost their jobs because of policy changes.

With two further reforms in 1986 and 1999 (Table 18.3), the unemployment program now aims to cover all urban employees (other than public servants). Insurance funds are contributed by employees and employers at the rate of 3 per cent of wages. The government also stands by to provide support if needed. Contributions are collected and pooled at the municipal level, with a provincial adjustment fund. ${ }^{10}$ The unemployment benefits include unemployment relief, medical care subsidies, funeral subsidies, and a lump sum subsidies for the dependants of deceased unemployed workers. The funds are also used to finance training and job-seeking

Table 18.2 Number of retrenched workers of SOEs, 1997-2001 (by year end)

\begin{tabular}{lccccc}
\hline & 1997 & 1998 & 1999 & 2000 & 2001 \\
$\begin{array}{l}\text { Number of retrenched workers } \\
\text { (million persons) }^{\mathrm{a}}\end{array}$ & 6.3 & 6.1 & 6.5 & 6.6 & 5.2 \\
$\begin{array}{l}\text { Total employees in state-owned work units } \\
\text { (millions of persons) }\end{array}$ & 109.5 & 107.7 & 88.1 & 83.3 & 78.8 \\
\hline
\end{tabular}

Note: a Figures do not include reemployed retrenched workers. ${ }^{b}$ State-owned work units include SOEs and other institutes and organisations.

Source: Author's calculations based on figures from MOLSS available online at http:// www.molss.gov.cn.tongji/gb. 
services for the unemployed (Kang and Feng 2000). The details of the benefits are determined by the provincial government. The maximum period of benefits is 24 months for employees with at least 10 years of contributions.

\section{PENSION REFORM}

The pension program is the most expensive scheme among the social security programs specified in the LIR (Figure 18.1).

By the late 1970s, the old pension program had evolved into an individual-SOE based 'pay-as-you-go' (PAYGO) system, where SOEs payed pensions to their retirees from current operating surplus. A series of reforms were introduced in the $1980 \mathrm{~s}$ and 1990s in response to the financial pressures generated by the scheme (Table 18.4).

The first reform involved pooling the pension funds of SOEs at county or city level. It required all SOEs to contribute to a pension fund at a given rate. The fund then distributed the funds back to each SOE according to their pension liabilities.

Figure 18.1 Expenditure of major social security programs in China, 1999

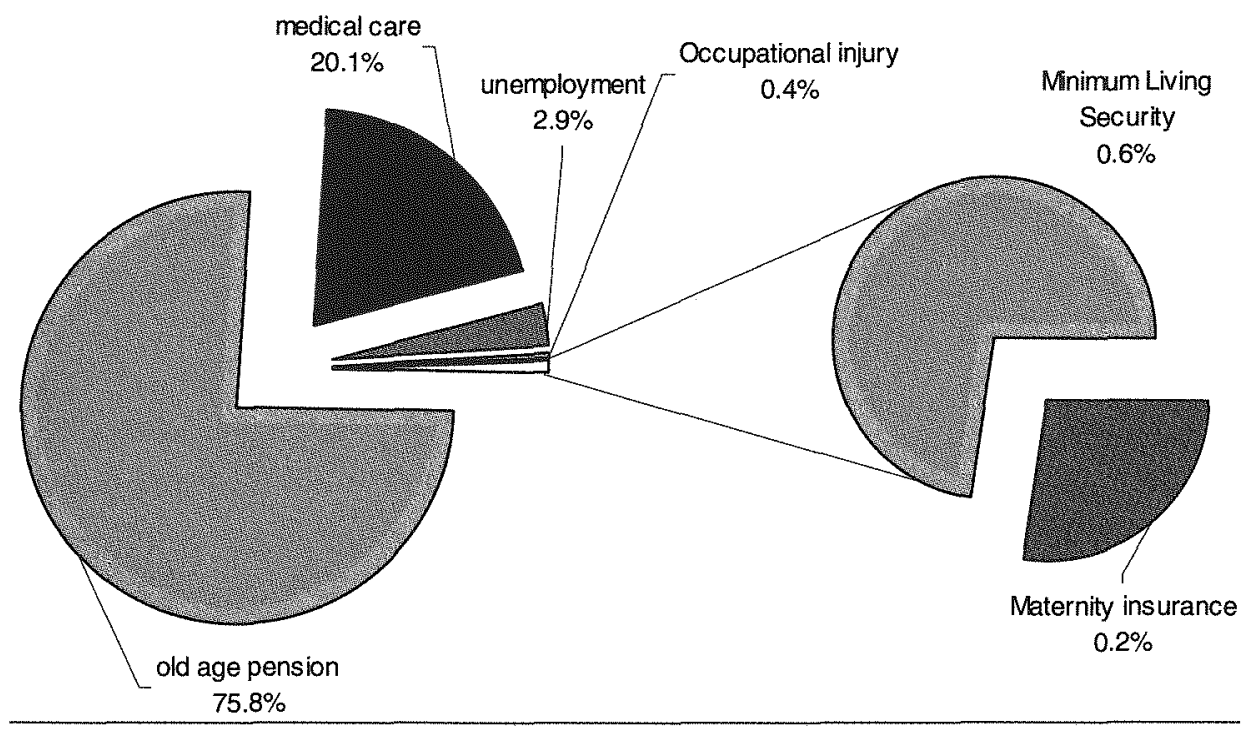

Source: Expenditures on old age pensions, medical care, unemployment insurance, occupational injury and maternity insurance are from State Statistical Bureau 2000. China Statistical Yearbook 2000, China Statistical Press, Beijing. Figures for minimum living security program are from Shi (2000). 
This was the first step towards risk sharing of pension liabilities among SOEs (Han and Jiao 1997, He 2000, Li 2000).

This social pooling of pension funds among SOEs was unsustainable. First, SOEs with a relatively older employee profile had more incentive to contribute, while those with a younger profile had no incentive to contribute. Second, the public sector, which was covered by the pension program, rapidly became 'older', while young people were attracted to the emerging private sector, which was not covered by teh program (Table 18.5). The nature of a PAYGO pension scheme is that it is only stable if it is centrally enforced by regulations. Once the potential for labour mobility was created by the new private sector, young people had an incentive to move into private firms, so as to avoid having to pay for the pensions of the old.

The pension scheme was further reformed in the 1980 s and 1990s (Table 18.4). Reforms at this stage included increasing contributions (employee contributions) and adjusting benefits. By the end of 1990s, the pension scheme had become a three-pillar system with (targeted) coverage of all urban employees.

Table 18.3 Summary of Chinese unemployment insurance reforms in the $1980 \mathrm{~s}$ and 1990s

\begin{tabular}{|c|c|c|c|}
\hline Time & 1986 & 1993 & 1999 \\
\hline Document & $\begin{array}{l}\text { Temporary insurance } \\
\text { regulation for SOE } \\
\text { employees waiting } \\
\text { for jobs }\end{array}$ & $\begin{array}{l}\text { Stipulation of } \\
\text { insurance for SOE } \\
\text { employees waiting for } \\
\text { jobs }\end{array}$ & $\begin{array}{l}\text { Rules of } \\
\text { unemployment } \\
\text { insurance }\end{array}$ \\
\hline Coverage & $\begin{array}{l}\text { Four categories of } \\
\text { ex-employees of SOEs }\end{array}$ & $\begin{array}{l}\text { Seven categories of } \\
\text { ex-employees of SOEs }\end{array}$ & $\begin{array}{l}\text { All urban employees, } \\
\text { except public servants }\end{array}$ \\
\hline Finance & $\begin{array}{l}\text { Employer contribution; } \\
\text { budgetary appropriation }\end{array}$ & $\begin{array}{l}\text { Employer contribution; } \\
\text { budgetary appropriation }\end{array}$ & $\begin{array}{l}\text { Employer contribution; } \\
\text { employee contribution; } \\
\text { budgetary appropriation }\end{array}$ \\
\hline $\begin{array}{l}\text { Unemployment } \\
\text { benefits }\end{array}$ & $\begin{array}{l}\text { Unemployment relief: } \\
\text { between } 50 \text { per cent } \\
\text { to } 75 \text { per cent of } \\
\text { standard wages }\end{array}$ & $\begin{array}{l}\text { Relief: } 20-50 \text { per cent } \\
\text { above social relief, }{ }^{a} \text { plus } \\
\text { medical care subsidy; } \\
\text { funeral subsidy and } \\
\text { dependant allowance; } \\
\text { Other benefits }\end{array}$ & $\begin{array}{l}\text { Unemployment relief } \\
\text { between social relief } \\
\text { and minimum wages; } \\
\text { medical care subsidy; } \\
\text { funeral subsidy and } \\
\text { dependant allowance; } \\
\text { Other benefits }\end{array}$ \\
\hline Duration & $12-24$ months & $12-24$ months & $12-24$ months \\
\hline
\end{tabular}

Note: a Social relief refers to the local poverty line, the minimum living security line, 
The first pillar is a scaled-down PAYGO system that provides the so-called elementary pensions. The second pillar is a compulsory, funded program of individual savings accounts that provides the so-called individual account pensions. The third pillar is a supplementary enterprise pension (Han and Jiao 1997; Liu 2000). It is expected that the first two pillars will provide a basic income-the basic pensionto retirees. ${ }^{11}$

Table 18.4 A summary of public pension reforms in the 1980 s and 1990 s

\begin{tabular}{|c|c|c|}
\hline Major reform & Coverage & Major reforms \\
\hline $\begin{array}{l}\text { Social pooling of } \\
\text { cities; later } \\
\text { pension funds (1984) }\end{array}$ & SOES & $\begin{array}{l}\text { Within a pooling area (initially counties and } \\
\text { provinces), SOEs contributed to a social } \\
\text { pooling fund according to a unified rate. } \\
\text { Pensions were then paid from the social } \\
\text { pool. }\end{array}$ \\
\hline $\begin{array}{l}\text { Fully-funded pension } \\
\text { scheme for contract } \\
\text { workers in SOEs (1986) }\end{array}$ & $\begin{array}{l}\text { Contract workers of } \\
\text { SOEs }\end{array}$ & $\begin{array}{l}\text { Employer: } 15 \text { per cent total wages of } \\
\text { contract workers. Employee: about } 3 \text { per } \\
\text { cent of wages. Contributed into separate } \\
\text { funds from the social pool of permanent } \\
\text { employees }\end{array}$ \\
\hline $\begin{array}{l}\text { Employee contributions } \\
\text { introduced for all } \\
\text { employees of } \\
\text { SOEs (1991) }\end{array}$ & $\begin{array}{l}\text { Employees of SOEs } \\
\text { and state-owned work } \\
\text { units }\end{array}$ & $\begin{array}{l}\text { Employee contribution about } 3 \text { per cent of } \\
\text { wages. Accumulated funds of contract } \\
\text { workers were combined with social } \\
\text { pooling funds of permanent employees of } \\
\text { SOEs. }\end{array}$ \\
\hline $\begin{array}{l}\text { Reforming pension } \\
\text { benefits (1993) }\end{array}$ & SOEs in pilot cities & $\begin{array}{l}\text { Pensions = social pensions+ contribution } \\
\text { pensions. Social pension }=15-25 \text { per cent } \\
\text { of local average wages in the previous } \\
\text { year. Contribution pensions: depend on } \\
\text { contribution years }\end{array}$ \\
\hline $\begin{array}{l}\text { Individual account, a } \\
\text { three-pillar pension } \\
\text { program (1995) }\end{array}$ & All urban employees & $\begin{array}{l}\text { A three-pillar pension system that } \\
\text { comprised: 1) elementary pensions } \\
\text { (PAYGO, social-pooling fund at the city or } \\
\text { county level); 2) individual account pinions } \\
\text { (privately owned individual accounts, fully } \\
\text { funded); and 3) other supplementary } \\
\text { pensions (half-voluntary, at enterprise } \\
\text { level. Still undergoing experiments). }\end{array}$ \\
\hline $\begin{array}{l}\text { Unification of pension } \\
\text { programs within } \\
\text { provinces (1997) }\end{array}$ & All urban employees & $\begin{array}{l}\text { All pension programs within each province } \\
\text { were required to be unified into one } \\
\text { scheme, in terms of contribution rate, } \\
\text { pension benefits, management of social } \\
\text { pooling funds and individual accounts, etc. }\end{array}$ \\
\hline
\end{tabular}


For the PAYGO component, the aim is to establish a social pool at the province level, with funds contributed by employers. The targeted contribution rate is 17 per cent. The elementary pensions-20 per cent of provincial average wages-are paid from this social pool to retirees with at least 15 years' contribution. ${ }^{12}$

For the funded component, funds are accumulated in individual accounts contributed by both employers and employees at a rate of 11 per cent of wages. Of this, employees contribute 8 per cent, and employers contribute 3 per cent. Retirees who contribute for more than 15 years receive monthly individual account pensions equal to $1 / 120$ of total funds in the account at retirement. Other retirees receive the accumulated funds (including credited interest) as a lump sum at retirement.

\section{THE URBAN MINIMUM LIVING SECURITY PROGRAM (UMLS)}

The Urban Minimum Living Security Program (UMLS) program is a new program for social relief. The old social relief program was based on the work unit, since work units looked after the employees and their families. Urban people with no work unit, ${ }^{13}$ no family, and no source of support from relatives-the so-called 'people without the three essentials' (sanwu)-were looked after by the MCA with limited assistance (Wang 1996; Zheng et al. 2000).

Table 18.5 Retiree/employee ratios by ownership structure in China, 1982-98

\begin{tabular}{lcccccc}
\hline & \multicolumn{3}{c}{$\begin{array}{c}\text { Retiree/ } \\
\text { Total } \\
\text { employees } \\
\text { (million) }\end{array}$} & $\begin{array}{c}\text { Total } \\
\text { retirees } \\
\text { (million) }\end{array}$ & $\begin{array}{c}\text { employee } \\
\text { ratio } \\
\text { (per cent) }\end{array}$ & $\begin{array}{c}\text { Retiree/employee ratios } \\
\text { (per cent) }\end{array}$ \\
1982 & 112.8 & 11.1 & 0.10 & 0.10 & 0.09 & state-owned \\
collectives & other units \\
1985 & 123.6 & 16.4 & 0.13 & 0.13 & 0.14 & 0.13 \\
1987 & 132.1 & 19.7 & 0.15 & 0.15 & 0.15 & 0.11 \\
1989 & 137.4 & 22 & 0.16 & 0.16 & 0.16 & 0.08 \\
1990 & 140.6 & 23 & 0.16 & 0.17 & 0.16 & 0.06 \\
1992 & 147.9 & 26 & 0.18 & 0.18 & 0.17 & 0.07 \\
1995 & 149.1 & 30.9 & 0.21 & 0.22 & 0.21 & 0.08 \\
1996 & 148.5 & 32.1 & 0.22 & 0.23 & 0.21 & 0.09 \\
1997 & 146.7 & 33.5 & 0.23 & 0.25 & 0.22 & 0.08 \\
1998 & 123.4 & 36 & 0.29 & 0.32 & 0.32 & 0.12
\end{tabular}

Source: author's calculation based on China Statistical Yearbook, 2001a. China Statistical Press, Beijing. 
During the early and mid 1990s, urban people in need could be broadly classified into three groups:

- residents who had local urban household registrations ${ }^{14}$ and were employed in the public sector

- other urban residents who had local household registrations

- migrants in cities who did not have local household registrations.

This last category included those from other cities, but the majority were from villages (Jiao 2002).

In terms of social relief provisions, the first group received the most generous benefits and were often entitled to be looked after by their work units, although in practice they did not always receive the benefits to which they were entitled. ${ }^{15}$ The second group received minor benefits (the social relief for 'people without the three essentials' from the MCA), while the third group had almost no social safety net. In terms of the need for social support, however, the order was opposite: the most needy were often the third group and the least needy were the first group.

The UMLS program was set up in 1997, designed to provide a guaranteed minimum per capita income for poor urban families (Wang 1999). It covers urban residents who have the local household registrations, but not the third category discussed previously-migrants.

The amount of relief for an UMLS recipient family is calculated by the following formula (all in terms of a month):

Total relief in yuan $=$ Local UMLS line $e^{\star}$ umber of household members

- Total calculated household income

The 'total calculated household income' may not be equal to the 'total actual household income'. The definition often changes slightly from city to city, which may detrimentally affect the poverty relief program.

The city government is responsible for the administration and funding of the program. It determines the local UMLS level and delivers the cash assistance. The provincial government regulates and coordinates the programs of the cities under its jurisdiction. The number of recipients as well as government expenses of the program rose rapidly during the first five years of the program's operation (Table 18.6). 


\section{CHALLENGES FOR THE PENSION SCHEME}

The pension scheme faces a few challenges

- an aging population, which indicates that the PAYGO scheme is not feasible

- financing the pension debt of the old PAYGO scheme in the new funded scheme during the economic transition

- reducing the taxation impact of the funded scheme.

\section{Population aging and the PAYGO pension scheme}

The Chinese population is projected to age rapidly during the first half of the $21^{\text {st }}$ century. This means that the financial burden of supporting the elderly with a PAYGO scheme is going to rise. The old-age dependency ratio-the ratio of the number of retired people to the number of working people--is rising sharply in China compared with other economies (Figure 18.2). In 2000, there were about six working people to support every old person in China. By 2050, there will be fewer than two working people to support each old person.

This population trend means that, in order to finance a defined-benefit (constant pension-wage ratio) PAYGO pension scheme from payroll tax, the tax rate will have to rise. Without other charges, the payroll tax rate in China would have to rise from 13 per cent in 2001 to 53 per cent in 2050 under this scenario (see Figure 18.3). ${ }^{16}$

Such a sharp rise in payroll tax rate would have significant efficiency costs, since the associated deadweight losses increase with the tax rate. A more efficient approach would be to smooth out the future high tax burden over a period of time ${ }^{17}$ by imposing a constant (optimal) tax rate to minimise the overall deadweight losses. Considering various possible future economic growth scenarios, this optimal tax rate needs to finance the old defined-benefit scheme in urban China-about 30 per cent. This tax rate, again, does not appear to be feasible.

The major conclusion of these results ${ }^{18}$ is that, with the rapid aging of the population, financing the old defined-benefit PAYGO pension scheme by collecting payroll tax in urban China is too expensive to be feasible. Even if the tax burden were evened out over a 50-year period, the optimal tax rate would have to be around 30 per cent of wages, which is not feasible either. 


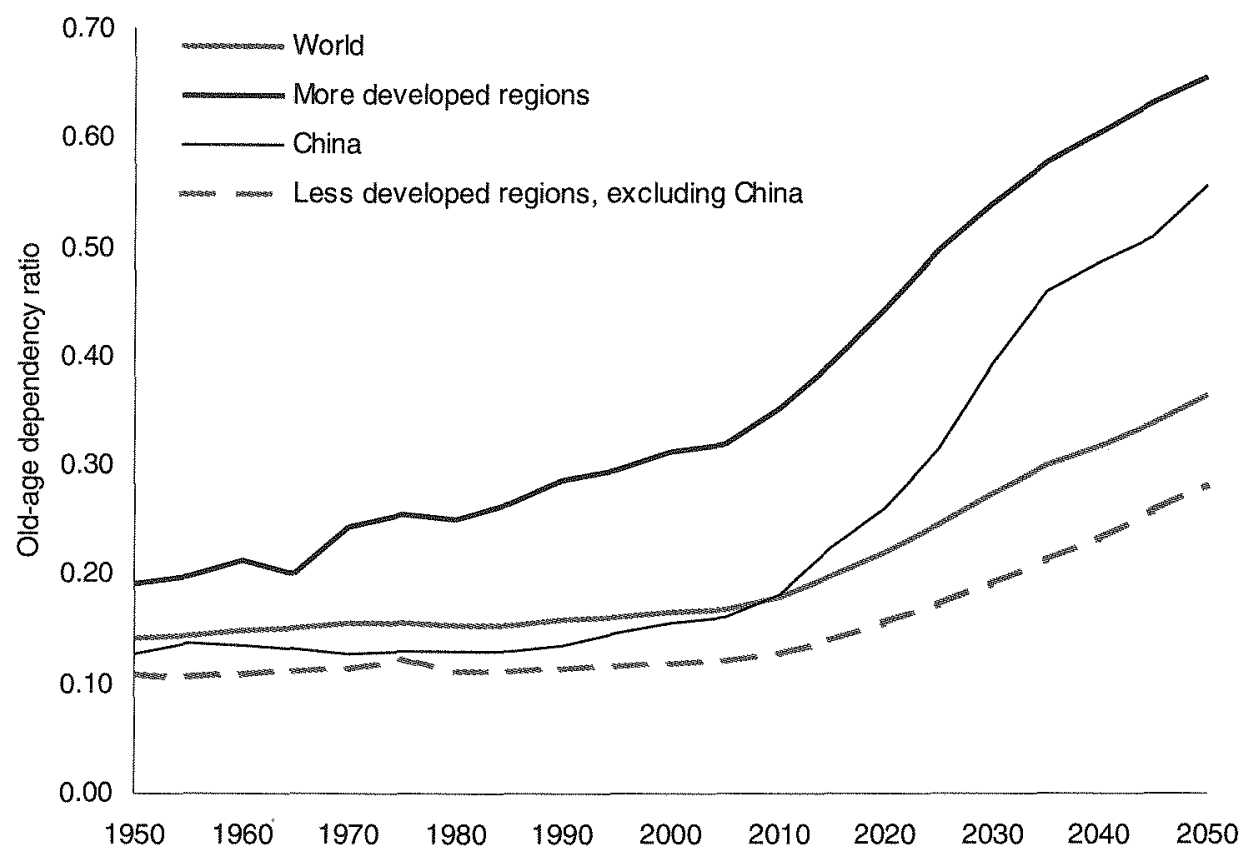

Note: The old-age dependency ratio is defined as the ratio of the number of people aged 60 and over to the number of people aged between 15-59. a The more developed regions comprise Europe, North America, Australia/new Zealand and Japan. ${ }^{b}$ The less developed regions include all regions in Africa, Asia (except Japan), Latin America and the Caribbean plus Melanesia, Micronesia and Polynesia.

Source: Author's construction based on United Nations, 2001. World Population Prospects: the 2000 revision, United Nations, New York

Table 18.6 Selected aggregate figures for the UMLS program, 1998-2002

\begin{tabular}{lccccc}
\hline Year & 1998 & 1999 & 2000 & 2001 & 2002 \\
Recipients (million persons) & 1.84 & 2.66 & 4.03 & 11.71 & 20.64 \\
Share of urban population (per cent) & 0.49 & 0.68 & 0.88 & 2.44 & 4.11 \\
Relief costs (billion yuan) & 0.7 & 2.37 & 3.45 & 5.00 & 10.87 \\
\hline
\end{tabular}

Source: Number of recipients and relief costs figures are from Ministry of Civil Affairs, various years. Urban population figures are from State Statistical Bureau, various years. China Statistical Yearbook, China Statistical Press, Beijing. 


\section{The pension debt, its finance and economic transition}

If the PAYGO pension scheme were reformed into a funded scheme, the government would have to finance the so-called 'transition costs', or the pension debt. This debt is not actually the cost of the pension reform. Instead, it is the implicit government debt accumulated during the PAYGO period, and becomes explicit when the scheme is to be changed to a funded one.

For a given economy, the size of the explicit pension debt depends on factors such as the coverage and benefits in the old PAYGO system and the age structure of the population covered. The pension debt in China is estimated to be low compared with that in countries such as Chile and Argentina when they reformed their systems (World Bank 1997). ${ }^{19}$

One way to examine the burden of the pension debt in China is to simulate the tax rate required to pay this debt. According to the World Bank (World Bank 1997), the scale of China's pension debt was about 50 per cent of GDP in 1996. Suppose the 2000 pension debt level is equal to the level in 2000 and that this pension debt is to be financed by collecting payroll taxe ${ }^{20}$ between 2001 and 2050 . The 50 -year period allows the government to distribute the burden of debt over time in order to minimise the deadweight losses due to the tax. ${ }^{21}$

In the simulation mentioned previously, the Chinese taxation system was assumed to be efficient, that is, one yuan payroll tax collected can be used to pay one yuan pensions, and there was no 'waste' in the taxation system. However, a more realistic assumption for an economy during the transition is to consider a taxation system that is not very efficient initially, but becomes more efficient over time. This is because the command economy had no 'regularised' taxation system (McMillan and Naughton 1992). ${ }^{22}$ A new taxation system needs to be established in a marketoriented economy and it takes time for the new system to begin operating efficiently. With this assumption, the optimal tax rate rises over time instead of being constant. ${ }^{23}$

Bearing in mind these assumptions, ${ }^{24}$ when the taxation system is as inefficient as it was in 2000 , the payroll tax rate for various scenario ${ }^{25}$ ranges from 1 per cent to 4 per cent. If the taxation system becomes more efficient over time, the optimal tax rate is even lower but rises during the 50 year period. Figure 18.4 shows the time path of the tax rate for three different growth rates of urban GDP, when the discount rate is 5 per cent a year. Obviously, when GDP per capita grows faster (and thus the wage rate increases faster), the taxation base for the payroll tax is bigger, and therefore the tax rate required for the pension debt is lower, ceteris paribus. 
These results indicate that the payroll tax burden to finance the pension debt of the old PAYGO scheme in China is not high at all, if the government plans to spread it over a few decades. Faster growth rates of the urban economy tend to reduce the tax rate.

\section{The high tax component of the current pension scheme}

While the current, three-pillar pension scheme is a partially funded program to face the challenge of an aging population, both of the first two pillars need further reforms. The scheme embodies a high tax component and may have a negative impact on economic efficiency.

Figure 18.3 The UN (2001) projected old-age dependency ratio and the PAYGO tax rate

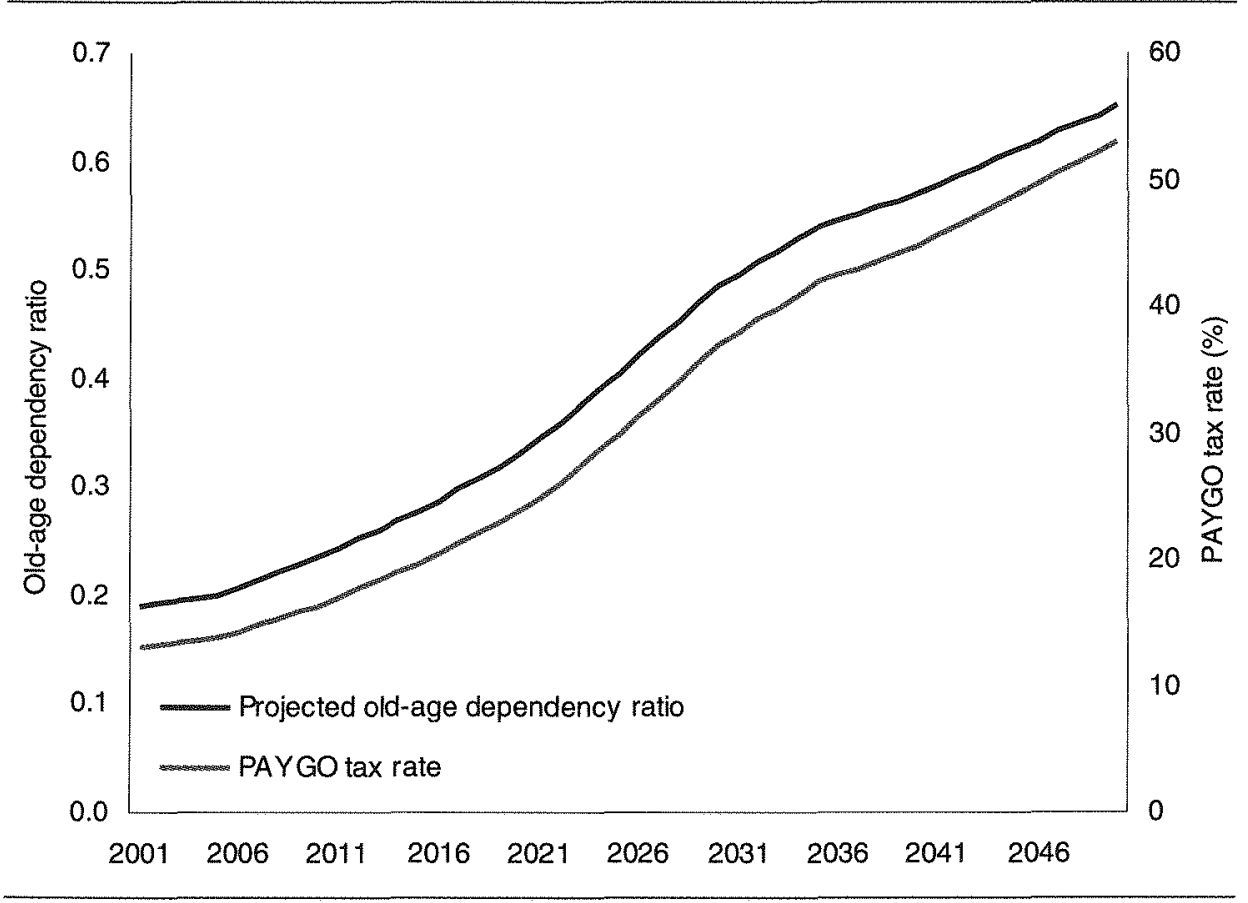

Source: ${ }^{1}$ The old-age dependency ratio is calculated by the author based on UN (2001) projections (medium variant of fertility assumption). It is the number of people at retirement age (males aged $60+$ and females aged 55+) to that at working age (males aged between 15 and 59 , females between 15 and 54). ${ }^{2}$ The year-by-year tax rate is from author's simulation results. Details are available upon requirement. 
First, the social pooling, or the PAYGO component, of the scheme has problems. This PAYGO scheme is unusual since it appears to have both defined benefits and defined contributions: 17 per cent contribution over at least 15 years provides an elementary pensions equal to 20 per cent of provincial average wages. To finance a pension scheme on a PAYGO basis, the fund is financially viable if the following condition holds:

$$
t=\frac{P}{W} * \frac{N_{R}}{N_{W}}
$$

where $P$ is the average pension, $W$ is the average wages, $P / W$ is the aggregate replacement rate; $N_{B}$ is the number of retirees, and $N_{W}$ is the number of workers, $t$ is the contribution rate (as a percentage of total wages).

According to Equation 18.1, a 17 per cent contribution (t) of wages would be sufficient to pay elementary pensions equal to 20 per cent $(P / W)$ of the average wages for a retiree-employee ratio up to 0.85 , if the scheme is financed on a yearby-year basis. This is a very high retiree-employee ratio, and far above the projected old-age dependency ratio of the Chinese population by 2050 .

In fact, the government intends to use this social pooling to finance the implicit pension debt of the old PAYGO scheme (Han and Jiao 1997). But funds in this pool have been insufficient to pay the debt in the past. This has contributed to the 'empty account' problem - some local governments have used funds in individual accounts to pay pensions to current retirees. The central government has had to bail out local governments as well. According to Zhao and Xu (2002:404), '[b]etween 1997 and 2000 , subsidies [by the central government to local governments to pay pensions] doubled every year-from over 5 billion yuan in 1997 to over 10 billion in 1998, over 20 billion in 1999, and over 40 billion in 2000'. In 2001, the subsidy was again 40 billion yuan (Zhao and Xu 2002). In 2002, it was 40.8 billion yuan, which accounted for over 14 per cent of pension payments (Ministry of Labour and Social Security 2003).

Social pooling has other problems. Since only employees with at least 15 years of contribution receive the 20 per cent elementary pension, workers who contribute for less than 15 years lose all their contributions into the social pool-a very high tax on these workers given that the contribution rate is 17 per cent of their wages. In addition, people who only contribute for relatively short periods because they are only employed for short periods may well be the group that most needs the 
Figure 18.4 Optimal payroll tax rate between 2001-50 to pay off historical pension debts up to 2000 , but not beyond*

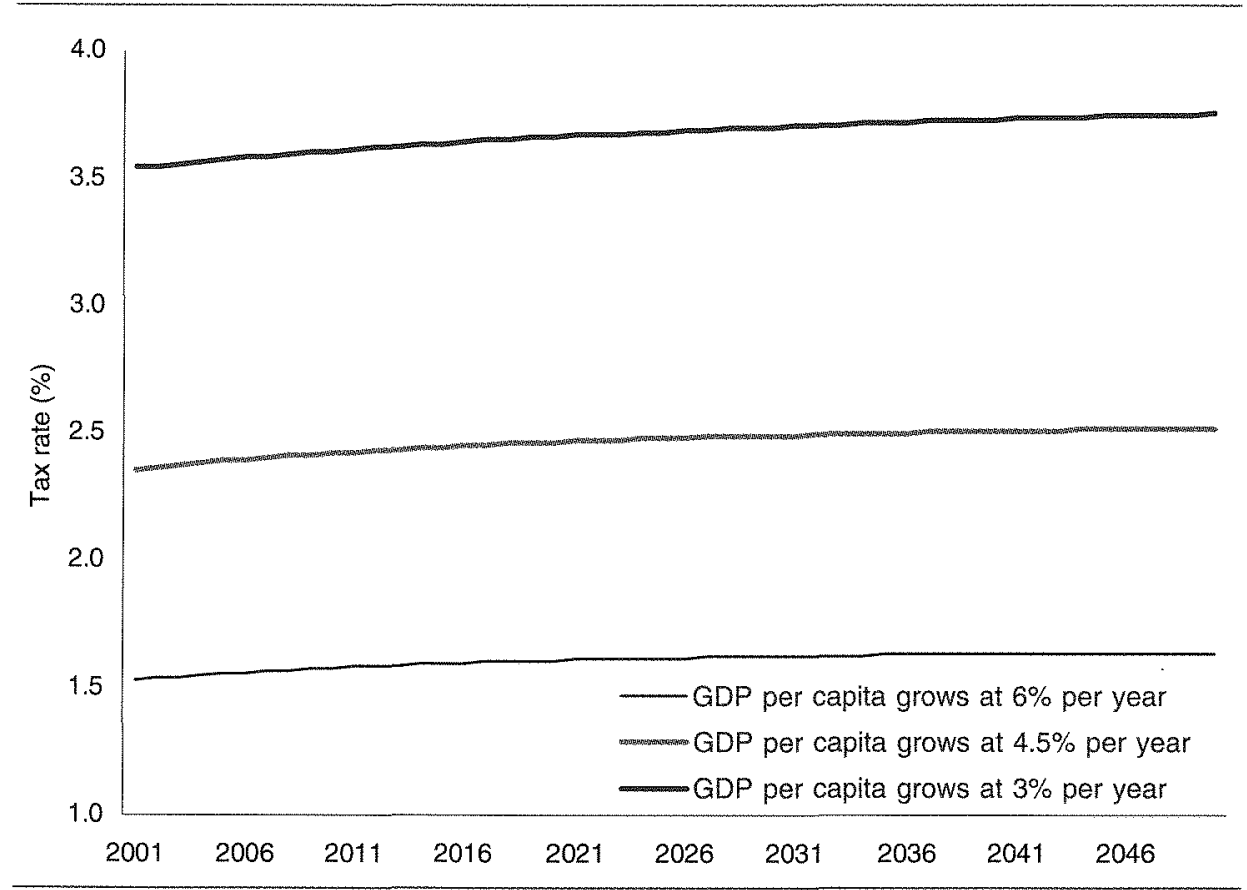

Note: * As explained in the text, this is the optimal tax rate required to collect just enough revenues (in 2000 values) to pay the accumulated pension debt of the old defined-benefit PAYGO scheme. Elasticity of labour supply $=1$; discount rate $=5 \% / y$ r.

Source: Author's simulation results.

government's assistance during retirement, since their lifetime income will probably be low. This income redistribution through the current system of social pooling misses the group who are more likely to be really poor.

Second, the funded component also has problems. To reduce the taxation impact of the contribution to individual accounts, the account must be individually owned, earn market returns and be fully portable. Although individual workers own their individual accounts, including both funds and returns, there is confusion in some regulations and practices regarding this ownership. For instance, in the case of the death of an employee, the relatives may inherit only part of the residual funds in the account-the employee contributions and accumulated interest earnings, but not the employer contributions. 
Currently, funds in individual accounts are not earning a market return. Instead, every year, the provincial government determines a rate of return, the 'accounting interest rate', with reference to bank deposit rates or rates of government bonds (Han and Jiao 1997; Liu 2000). Since the government controls the interest rate, this accounting interest rate tends to be lower than the market return. This implies that employees' labour income is taxed by the pension scheme.

This problem is exacerbated by the fact that provincial governments have an incentive to choose a low interest rate for pension funds. As part of a mandatory public pension scheme operated at the province level, the accounting interest rate affects the future liabilities of the local government. The higher the interest rate chosen to calculate the return on pension funds, the higher the future liabilities of the local government to account owners.

Regulations allow for individual accounts to be fully portable, but how feasible this portability is in practice needs to be monitored closely. This could cause problems if people working in a low-wage province move to a high-wage province owing to the future elementary pensions paid from the social pool.

There are also problems with the management of individual accounts. One example is the 'empty account' problem, when funds in individual accounts are used to pay pensions for current retirees or to invest in local infrastructure, real estate or stocks (Han and Jiao 1997; Li 1998). From an employee's point of view, the key issue is whether or not the local government, as the management authority of their individual accounts, can pay back the money in the account when the employee retires. As long as employees believe that their future pensions from their individual accounts are secure, they will regard the pension contribution into their individual account as part of their deferred payment rather than taxes..$^{26}$ Provided the government's assets, including its future tax revenues, are sufficient to finance its liabilities, they will be all right.

Otherwise, either of the following, or both, may happen: the local government would have to raise taxes or reduce expenditures, or the central government will have to bail out provincial governments in order to keep the scheme running or retirees would receive less than they were promised. In the former case, the government would have to impose more taxes on the private economy, and this would change the nature of the supposedly funded scheme to one that is essentially PAYGO, but with individual accounts. In the latter case, the supposedly individual accounts will turn out not to have been genuinely individual accounts. 
One way to examine the tax component of the current pension scheme is shown in Table 18.7. Suppose there is a hypothetical pension scheme, Scheme $\mathrm{H}$, which has the same contribution rate (28 per cent of wages) as the current scheme, but in which all contributions are accumulated in workers' individual accounts. For simplicity, also assume that, in Scheme $\mathrm{H}$, pensions paid from individual accounts are equal to $1 / 120$ of funds available at retirement, as in the current scheme. The replacement rates of the current Chinese pension scheme and of Scheme $\mathrm{H}$ are listed in Table 18.7. For convenience, the results are calculated for workers whose real wages are equal to the local (provincial) average wage. It is also assumed that the return on funds in individual accounts is the same as the growth rate of wages, and that pensions grow at the same rate as wages. The retirement period is assumed to be ten years. ${ }^{27}$

The comparison between columns $A$ and $B$ shows that, with the same contribution rate, workers receive a higher pension (shown as higher replacement rates) in Scheme $H$ than in the current Chinese pension scheme, regardless of the length of working/ contribution period. In fact, it is clear that the longer the contribution, the more significant the difference is ${ }^{28}$

Table 18.7 Contributions, employment and replacement rate of pensions

\begin{tabular}{|c|c|c|c|c|}
\hline $\begin{array}{l}\text { Years of } \\
\text { employment } \\
\text { contribution }\end{array}$ & $\begin{array}{l}\text { Replacement } \\
\text { rate of the } \\
\text { current Chinese } \\
\text { pension scheme } \\
\text { (per cent)(A) }\end{array}$ & $\begin{array}{c}\text { Replacement } \\
\text { rate of } \\
\text { scheme } H \\
\text { (per cent)(B) }\end{array}$ & $\begin{array}{l}\text { Contribution rate } \\
\text { required for the } \\
\text { same } \\
\text { replacement } \\
\text { rate as }(A) \\
\text { (per cent) }(C)\end{array}$ & $\begin{array}{c}\text { Excess } \\
\text { contribution } \\
\text { rate of the } \\
\text { current Chinese } \\
\text { pension scheme } \\
\text { (percentage points) }\end{array}$ \\
\hline 10 & $11.0^{\mathrm{b}}$ & 28.0 & 11.0 & 17.0 \\
\hline 15 & $36.5^{\mathrm{c}}$ & 42.0 & 24.3 & 3.7 \\
\hline 20 & 42.0 & 56.0 & 21.0 & 7.0 \\
\hline 25 & 47.5 & 70.0 & 19.0 & 9.0 \\
\hline 30 & 53.0 & 84.0 & 17.7 & 10.3 \\
\hline 35 & 58.5 & 98.0 & 16.7 & 11.3 \\
\hline 40 & 64.0 & 112.0 & 16.0 & 12.0 \\
\hline
\end{tabular}

Note: Replacement rate is calculated as the ratio of the first month's (year) pensions to the last month's (year) wages. ${ }^{b}$ Workers with less than 15 years of contribution are not eligible for the 20 per cent local average wage. The number is calculated assuming pensions for the first month of retirement are paid as $1 / 120$ of total funds in the individual account. " This and the following replacement rates in column $A$ include 20 per cent of the local average wage. ${ }^{d} \mathrm{Here}$, all contributions are accumulated in individual accounts.

Source: Author's calculation. 
Another way to see the difference between the two schemes is to look at extra pensions gained with longer years of contribution. While an extra 20 years of contribution (from 15 to 35 years) brings an extra 20 percentage points of replacement rate for workers in the current Chinese pension scheme, it would bring an extra 46 percentage points for the same workers if they were in Scheme $\mathrm{H}$ (comparing columns $A$ and $B$ ).

Column $\mathrm{C}$ in Table 18.7 shows the contribution rate (percentage of wages) required of workers in Scheme $\mathrm{H}$ in order to achieve the same replacement rate as the current Chinese pension scheme. Obviously, the longer the contribution period, the lower the contribution rate required to receive the same pension as in the current Chinese pension system. ${ }^{29}$ This demonstrates that workers bear a higher tax burden the longer they stay in the current Chinese pension system. This is shown in the last column in Table 18.7, where these calculated contribution rates are subtracted from the contribution rate of the current Chinese pension scheme, which is 28 per cent. The results can be regarded as the excess contribution rate of the current Chinese pension scheme compared with Scheme H.

\section{CHALLENGES FACING THE REFORM OF THE UMLS PROGRAM}

\section{The failure of the UMLS to provide a safety net to all residents}

As discussed earlier, the UMLS program only covers people with the local (urban) household registration. This means that a large proportion of people living in cities are not protected by this safety net, although many are poor.

Since the mid 1980s, policies that curbed labour mobility during the pre-reform era have become less effective (Zhao 2003). In the meantime, surplus rural labour has been 'pulled'30 and 'pushed'31 towards cities (Hare 1999; Wang 2001; Zhao 2003). Most of these migrants are not allowed to register as urban households and consequently face discrimination in terms of social and economic entitlements (Meng 2000; Jiao 2002; Zhao 2003). These migrants are often referred to as the 'floating population' (Li2001).

There is no consensus about the size of the floating population in Chinese cities. However, various sources indicate that, during the early 1980s, it accounted for less than 12 per cent of the urban population. ${ }^{32}$ By the mid 1990s, it accounted for 
about 23 per cent (see Rawski and Mead 1998; Wang 2001; Jiao 2002; Rozelle et al. 2002; Jiang 2003). ${ }^{33}$

The limited coverage of the UMLS program has two problems. First, it excludes the poor groups in cities - rural migrants-from the social safety net, even though they contribute to the urban economy. Second, the local household registration requirement, and the difficulty of obtaining it, can reduce labour mobility, especially for urban people. Poor people in one city may choose to rely on the local UMLS relief instead of going to other cities where there are more job opportunities, since they are denied the access of a safety net in these cities.

\section{The high implicit tax of the UMLS program}

The current UMLS program imposes a high tax rate on its recipients. The amount of cash received by the recipient is dependent on household income. When a recipient's household income is increased by one yuan, the recipient household loses one yuan from the UMLS program. This feature effectively imposes a 100 per cent marginal tax rate on recipients' earned income. The recipient is not financially better off by working more and earning more income, so long as they remain a UMLS recipient.

Of course, the 100 per cent marginal tax rate would be less relevant if an effective minimum wage were in place that was much higher than the city's UMLS line, and if part-time work were not available. ${ }^{34}$ On average in 1999 the UMLS line was about 60 per cent of the minimum wage for the capital cities. Taking this figure, suppose that the average family size is three people: two parents and one child. ${ }^{35}$ Suppose only one parent worked in 1999 and received the minimum wage and the family had no other income, then the per capita income of this family would be about 56 per cent of the local UMLS line. Therefore, this family would be eligible for the UMLS poverty relief and would face a tax rate of 100 per cent on any family earnings. That is not sufficient to raise per capita above the local UMLS line.

However, for some unemployed people, the relevant choice is between full-time employment and unemployment. For such people, the effective rate of tax on earned income is less than 100 per cent, particularly if minimum wage rates are actually enforced. For example, using the figures for the UMLS line and provincial minimum wage rates in 1999, a full-time job at the minimum wage for a month would typically pay about 67 per cent more than the monthly UMLS benefit. As a result, the average 
effective tax rate facing a person choosing between the UMLS benefit and full-time employment at the minimum wage would be 60 per cent, not 100 per cent. This is still a very high and distortionary implicit tax.

This high marginal tax rate has a strong negative impact on the labour supply. From the government's point of view, a social safety net that provides a minimum living for the poor is most efficient when the cost is minimised. One way to achieve this object is to minimise the number of people who rely on poverty relief, ceteris paribus. For this purpose, the design of the safety net must consider its negative impact on people's efforts to find jobs.

\section{CONCLUSIONS}

In addition to the problems of rapid population aging, reform of the social security system faces the challenge of the dynamic nature of the economic transition. If the government wishes to explore all possible benefits of the market, reforms to the social security system need to take into consideration ways of minimising the efficiency costs. These costs, such as possible disincentive impacts on labour supply and labor mobility, are particularly significant in the long run.

Some reforms are possible in the current social security system in order to reduce these disincentive effects.

- The contributions to the social pooling funds of pensions need to be reduced or eliminated. This will reduce the tax component of pension contributions on workers.

- The management of individual accounts must be improved to reflect the ownership of the accounts, to raise the return on pension funds to the market return and to minimise the possible impact on labour mobility. This reduces the perceived tax component of contribution to individual accounts.

- The pension debt of the old PAYGO scheme is not high for China. The most efficient way to finance this public debt is to spread the (payroll) tax burden over a long period of time, and to impose lower tax rates when the taxation system is not very efficient, but higher tax rates when it becomes more efficient. Faster economic growth helps to reduce the tax burden.

- For the UMLS program, the high and distortionary tax rate on earned income needs to be abolished. Further reforms of this program also need to consider the provision for migrants and how to reduce the barrier of labour mobility. 


\section{ACKNOWLEDGMENTS}

This paper is based on the author's PhD thesis, completed in June 2003 at the Economics Division, Research School and Pacific and Asian Studies, the Australian National University. The author would like to thank the supervisory panel, including Professor George Fane, Dr. Xin Meng and Professor Ross Garnaut, for their comments on drafts of the thesis

\section{NOTES}

1 The People's Commune was an organisation established by the Communist government. It combined the function of the lowest level government with economic management in rural China. It was the institution that facilitated the role of the agricultural sector in the command economy: a net contributor to the national economy.

2 The work unit was a general name for all sorts of organisations of the command economy, such as schools and factories. It could be state-owned or collective-owned. Each work unit was under the administration of a level of government or its agents. This in turn formed the hierarchy of the work unit system. The work units also combined economic activities with some government social functions, such as social security provisions.

3 The LIR covered state-owned and large collective firms. Employees in other public sectors had social security provisions similar to the LIR.

4 The HRS requires each citizen to register at the local police station, either as rural or non-rural (urban) resident. There are severe restrictions on people living in places other than their registered area.

5 The term 'social security' covers a wide range of programs in China; for example, see Shao and Chen (1991).

6 Wang and $\mathrm{Hu}$ (2001) have an interesting discussion with regard to the declining state fiscal capacity in China since the economic reform.

7 The SOE reforms in China have been well documented, for example, Dong, Tang and Du (1995), Walder (1996), Hay et al. (1994), and Gao (1999).

8 Here 'work units' is replaced with 'SOEs' since most reforms have occurred in SOEs.

$\vartheta$ At the time, the official notation was 'waiting for jobs' rather than 'unemployment' (see Tabie 18.3).

${ }^{10}$ This allows the provincial government to pool the risk among cities under its jurisdiction.

"Policies and detailed regulations with regard to the third pillar are yet to be formalised by the government.

12 This included years of employment acknowledged according to the government rules, which may or may not be equal to the actual working years of the individual (Liu 2000). 
${ }^{13}$ During the pre-reform period, once an individual was allocated to a work unit, the employment relationship was permanent. The work unit was also supposed to take care of the individual and his/her family for lifetime.

${ }_{14}$ This refers to the household registration at the city level, since moving within a city is not restricted by the HRS.

15 This was often due to the financial difficulties of their work units and the reduction of government subsidies to SOEs in deficit during the SOE reform.

${ }^{16}$ This is based on author's simulation, taking into account the difference between urban population aging and overall population aging, and assuming the replacement ratio is the same as the average replacement ratio in 2000 .

17 Barro (1979) shows that the optimal tax rate over time for a given public expenses is a constant tax rate in each period.

18 The author will supply details of the simulation and results of other scenarios of the simulation upon request.

19 The World Bank (1997) estimates that the implicit pension debt in China in 1994 was about 4669 per cent of GDP that year. Compared with 100-200 per cent in most OECD countries, and 40-130 per cent in Chile (depending on the discount rate chosen), the implicit pension debt in China is not very high.

20 Assume this payroll tax is the only tax imposed on the payroll. If there were already other payroll taxes, the tax rate required would be a little higher.

27 In the simulations, this pension debt is rescaled to 2000 values. This approach means that the discount rate matters. In the simulations, several discount rates are used to examine the sensitivity of the results.

22 Government revenues mainly came from the operating surplus of firms it owned (McKinnon 1991).

$\approx$ This can be shown mathematically in the model for the simulations.

${ }^{24}$ It is also assumed that pensions for future retirees of the new funded scheme are financed by accumulated pension contributions, and these contributions are not regarded as tax.

25 These different scenarios include different growth rates of urban GDP per capita and different values of the discount rate.

${ }^{2}$ Assuming the return is the same as the market return.

With this assumption, the formula (for the discrete case) for calculating replacement rate is simplified as

$$
\mathrm{B}=\frac{\mathrm{T}^{*} \tau}{10}
$$


where $B$ is replacement rate, $T$ is number of years of contribution, and $\tau$ is the contribution rate. This formula follows the practice in the current Chinese pension scheme that the first year pensions equal to $1 / 10$ of funds available in the individual account.

${ }^{23}$ Except for the case with only 10 years of contributions, when the worker does not receive the 20 per cent elementary pension from the social pooling fund.

2 With the exception of the case for the shortest contribution period, 10 years.

\$o Farmers are pulled towards cities and villages by, among other things, higher incomes and living standards.

31 Improved agricultural production efficiency and the consequent surplus labour in rural areas are among the factors that pushed farmers to cities.

32 This is calculated by assuming the floating population was 30 million, and those with urban household registration was, on average, 226.1 million between1981-85 (State Statistical Bureau 2000a)

36 This is calculated by assuming the floating population was 80 million in 1995 .

${ }^{34}$ Legislation governing minimum wages in China was issued in 1993 (Kang and Feng 2000).

35 The average family size in 1999 was 3.14 persons (State Statistical Bureau 2000b).

\section{REFERENCES}

Barro, R.,1979. 'On the Determination of the Public Debt', The Journal of Political Economy, 87(5):940-71.

Dong, F.R., Tang, Z.K. and Du, H.Y. (eds), 1995. Studies of Institutional Reform of Chinese State-owned Enterprises, Renmin Publishing House, Beijing.

Gao, S.Q., 1999. Two Decades of Reform in China, World Scientific Press, Singapore. Han, L. and Jiao, K. (eds), 1997. The Unification and Implementation of Enterprise Old Age Pension System, China Human Resource Press, Beijing.

Hare, D., 1999. "Push" and "pull" factors in migration outflows and returns: determinants of migration status and spell duration among China's rural population', Journal Development Studies, 35(3):45-72.

Hay, D.A., Morries, D.J., Liu, G. and Yao, S., 1994. Economic Reform and Stateowned Enterprises in China, 1979-1987, Clarendon Press, Oxford.

He, P., 2000. Choice of the Century: the framework of Chinese social security system, China Labor and Social Security Publishing House, Beijing.

Jiang, X., 2003. 'China perspective: debates initiated by the 'Song of Peasant Workers', BBC News online. Available at http://news.bbc.co.uk/hi/chinese/ china_news/newsid_2857000/28576.stm. 
Jiao, J., 2002. 'From the angle of the rights of the floating population', Population and Economics, 132(3):73-75.

Kang, S. and Feng, W. (eds), 2000. Selected Regulations of Current Social Security System, China Labor and Social Security Publishing House, Beijing.

Li, R., 2001. 'A preliminary study of local regulations of migrants', Population and Economics, 128(5):17-22.

Li, S., 1998. Old Age Pension Scheme and Capital Market, China Development Publishing House, Beiling.

$\mathrm{Li}, \mathrm{S}$., 2000. 'The predicament and way out of old age insurance', Comparative Economic and Social Systems, 3:37-45.

Liu, X. (ed.), 2000. The Old Age Insurance, China Labor and Social Security Publishing House, Beijing.

McKinnon, R.I., 1991. 'Financial control in the transition from classical socialism to a market economy', Journal of Economic Perspectives, 5(4):107-22.

McMillan, J. and Naughton, B., 1992. 'How to reform a planned economy: lessons from China', Oxford Review of Economic Policy, 8(1):130-43.

Meng, X., 2000. Labour Market Reform in China, Cambridge University Press, Cambridge.

Ministry of Civil Affairs, various years. Annual Public Statistical Report for Civil Affairs, Ministry of Civil Affairs, Beijing. Available online at http://www.mca.gov.cn/ news/dibao.

Ministry of Labour and Social Security, 2003. 2003 Annual Public Report of Labour and Social Security Development, MOLSS Report, Beijing. Available online at http://www.molss.gov.cn/tongji/gb.

Peterson, P.G., 1999. Grey Dawn, Random House, New York.

Rawski, T.G. and Mead, R.W., 1998. 'On the trail of China's phantom farmers', World Development, 26(5):767-81.

Rozelle, S., De Brauw, A., Huang, J., Zhang, L. and Zhang, Y, 2002. The Evolution of China's Rural Labour Market during the Reform, Working Paper 02-003, Department of Agricultural and Resource Economics, University of California, Davis.

Shao, L. and Chen, X., 1991. Social Security System Reforms in China, Economic Management Press, Beijing.

Shi, Z., (ed.), 2000. Reports on Chinese Social Welfare and Social Progress in 1999, Social Science Literature Press, Beijing. 
State Statistical Burea, 2001a. China Labour Statistical Yearbook, China Statistical

Press, Beijing.

- 2000b. China Statistical Yearbook, China Statistical Press, Beijing.

United Nations, 2001. World Population Prospects: the 2000 revision, United Nations, New York.

Walder, A.G. (ed.), 1996. China's Transitional Economy, Oxford University Press, Oxford.

Wang, A., Liu, Z., et al. (eds), 1998. Weaving Social Security Net: yesterday, today and tomorrow of the Chinese social security system, Guangxi Normal University Press, Guilin.

Wang, H., 1996. 'Urban Social Relief', in Li, B. and Jiang, W. (eds.), Disaster Relief and Social Relief, China Social Publishing House, Beijing: 145-217.

Wang, $H$. ., 1999. 'An institutional invention of urban social relief in China-The background, contents and implications of the Urban Minimum Living Security System', in D. Xu, Z. Yin and Y. Zheng (eds), Social Security Reform in China: papers selected from the International Forum on Social Security in China, 1998, Beijing, Economic Science Press, Beijing:666-676.

Wang, M., 2001. 'A summary of studies about China's floating rural labour force', in Institute of Population and Labour Economics (ed.), Almanac of China's Population, Almanac of China's Population Press, Beijing:112-20.

Wang, S.G. and Hu, A.G., 2001. The Chinese Economy in Crisis, M.E. Sharpe, New York.

Wen, T.J., 2000. Studies of Fundamental Economic Institutions in Rural China, China Economics Publishing House, Beijing.

World Bank, 1997. Old Age Security: pension reform in China, World Bank, Washington DC.

Zhang, Z., 1999. 'Ownership reforms', in Z. Zhang, F. Huang, and G. Li (eds), Twenty Years of Economic Reform: retrospect and prospect, China Planning Press, Beijing:21-43.

Zhao, Y., 2003. 'Rural to urban labour migration in China: the past and the present', in L. West and Y. Zhao (eds), Chinese Rural Labour Flows, University of California Press, Berkeley.

Zhao, Y. and Xu, J., 2002. 'China's urban pension system: reforms and problems', Cato Journal, 21(3):395-414. 
Zhao, Y. and Wen, G., 1999. 'Chinese rural social security and the land system', in D. Xu, Z. Yin and Y. Zheng (eds), Social Security Reform in China: papers selected from International Forum on Social Security in China, 1998, Beijing, Economic Science Press, Beijing:709-25.

Zheng, B., Wang, C., et al. (eds), 2000. Research of Urban Minimum Living Security Program in Southwest China, Southwest University of Finance and Economics, Chengdu, China, 